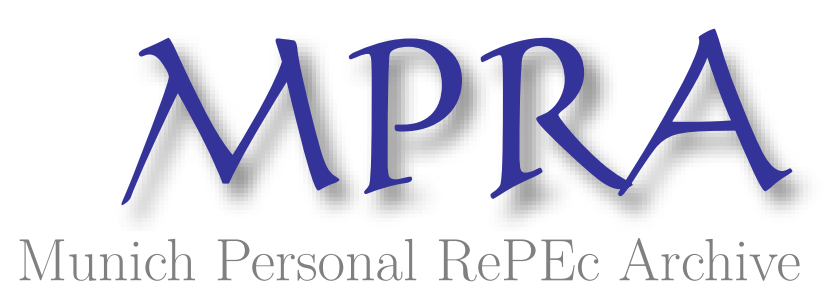

\title{
The Asian crisis and financial and capital account liberalization
}

Kant, Chander

Seton Hall University

2005

Online at https://mpra.ub.uni-muenchen.de/94845/

MPRA Paper No. 94845, posted 10 Jul 2019 15:35 UTC 


\title{
The Asian Crisis and Financial and Capital Account Liberalization ${ }^{\mathrm{a}}$
}

By

\section{Chander Kant*}

\begin{abstract}
One of the puzzling phenomena recently had been the sudden drop of external confidence in five Asian economies: South Korea, Indonesia, Malaysia, Thailand and the Philippines. The persistence, wide-impact, and underlying causes of this Asian crisis sets itself apart from the earlier Chilean and Mexican experiences. After discussing various explanations of this crisis, low marginal productivity of capital, Minsky's financial instability hypothesis, fixed exchange rates and un-hedged borrowings, 'push' factors and rise in country risk, regionalization and contagion, and institutional factors, it compares it to the Chilean and Mexican Crises. It emphasizes the need for the developing countries to strengthen their institutions at the same pace as they liberalize their financial sector and open-up their capital accounts.
\end{abstract}

Keywords: Minsky's financial instability hypothesis, Institutions, Chilean and Mexican Crises.

JEL Codes: F32, F36

${ }^{a}$ Accepted for publication in Economic Globalization In Asia, Edited by Partha Gangopadhyay and Manas Chatterji

*Department of Economics, Seton Hall University, 400 South Orange Avenue, South Orange, NJ 07078, U.S.A. Tel.: 973-761-9281, Fax: 973-761-9217 


\section{The Asian Crisis and Financial and Capital Account Liberalization}

\section{Introduction}

One of the puzzling phenomena recently had been the sudden drop of external confidence in five Asian economies: South Korea, Indonesia, Malaysia, Thailand and the Philippines. This lack of faith spread in varying degrees to other 'miracle economies' like Singapore, Taiwan, and Hong Kong. The abrupt change in fortunes was shocking because even as late as June 1997, policy makers and economists were trying to imitate these miracle economies. Now, the attempt is to learn how to avoid such a pointed discontinuity in economic performance.

Given the relative novelty of this crisis, theoretical analysis of this crisis is relatively sparse. Some parallels to the Mexican crisis of 1994-95 and the Chilean crisis of 1982-84 can be found. All these crises were accentuated by sharp reversal in the non-traditional external financing sector, viz. external financing not mediated or guaranteed by governments. Yet, as we shall see below, the persistence, wide-impact, and underlying causes of the Asian crisis sets itself apart from the earlier Chilean and Mexican experiences.

\section{Crises and the Asian Crisis}

Surveying crises faced by developing countries since 1960, Bruno (1996) distinguishes between three kinds of economic crises: inflation, debt, and growth. Inflation crisis is defined as high inflation followed by stabilization. High inflation means 40 percent annual inflation for at least two years in a row. Stabilization implies returning below that threshold for at least two years in a row. On the other hand, countries rescheduling their private debt at least once since 1980 are said to be facing debt crisis. Lastly, at least three consecutive years of decline in economic activity 
(cumulating to a drop of at least 9 percent in GDP) is defined as growth crisis. We present data on the recent Asian crisis to see whether these countries faced any of these crisis. ${ }^{1}$

Asian crisis manifests itself first by a sharp decline in exchange rates and asset values. The IMF, the World Bank, Asian Development Bank, and individual countries like Japan had committed \$117.7b to Indonesia, Korea, and Thailand by August 31, 1997. Also, Hong Kong has a large stock of foreign reserves, and has one of the most liberal and open financial markets in the world with its currency's long-standing peg to the U.S. dollar. Yet, the financial markets in Korea and Hong Kong suffered great turbulence in October 1997 (following Taiwan's depreciation of its new dollar by 10 percent).

Tables 6.1 and 6.2 present information on the decline in exchange rates and stock indices, respectively, in East Asian countries since July 1, 1997. Five countries stand out as having extreme exchange rate and stock value depreciations. These are Indonesia, Korea, Malaysia, the Philippines, and Thailand. ${ }^{2}$ Out of these five economies, Indonesia, Thailand, and Korea had to reschedule their private debt. Although inflation was expected to increase in these countries due to sharp exchange rate depreciation, it has remained moderate due to outflow of $\$ 17.2 \mathrm{~b}$ ), and a decline of $\$ 15.8 \mathrm{~b}$ in non-bank private creditors, and a decrease of $\$ 15.4 \mathrm{~b}$ in portfolio equity investment (from an inflow of $\$ 13.9 \mathrm{~b}$ to an outflow of $\$ 1.5 \mathrm{~b}$ ). These three declines account for 72 percent, 15 percent, and 14 percent, respectively, of the decrease in private inflows to the five Asian countries. The severe reversal of commercial bank and other private lending, rather than the reverse flow of securitized international finance, thus predominantly explains the sharp declines in the exchange rates and in other asset values in these countries. 


\section{Financial and Capital Account Liberalization}

In this section, we briefly summarize some of the recent work on financial and/or capital account liberalization both in general and that in Asia. We first note that liberalizations are often partial and incremental. Till the recent imposition of controls by Hong Kong and Malaysia, each year more and more emerging markets were moving slowly but steadily towards greater liberalization of their capital accounts and financial sectors. ${ }^{3}$ Few emerging markets had full liberalization. Nevertheless, fairly large capital movements may take place even with partial and incomplete liberalization.

Demirglic-Kunt and Detragiache (1998) study a large panel data set covering 53 industrial and developing economies during 1980-95. During this period the banking sector was increasingly liberalized. Yet, the frequency of systematic banking problems markedly increased, raising the possibility that greater fragility is a consequence of liberalization. Although financial fragility is affected by a host of factors, financial liberalization can be seen to have a negative effect on banking sector stability. Their findings strongly suggest that institutional development and the regulatory framework needed for financial markets to operate efficiently should be emphasized early in the liberalization process. There appears to be a consensus that ending financial repression is a precondition for freeing capital accounts. Yet, few authors have investigated the interaction between these two sectors after they are liberalized. One exception is Goldfajn and Valdes (1997) who through a three-period, three-agents (investors, financial intermediaries, and central bank) model show that intermediaries' role of transforming maturities results in larger movements of capital and higher probability of crisis. Haggard and Maxfield (1996), and Park (1994) also caution about rapid financial and capital account liberalization, particularly in a regime of fixed exchange rates. On the other hand, Bartolini and Drazen (1997) 
model a situation of foreign uncertainty about government's attitude towards taxation of capital. In this situation, a liberal capital outflow policy sends a signal of future favorable policies towards foreign investment and hence may trigger a capital inflow. This conclusion is supported by Mathieson and Rojas-Suarez (1993) who report that portfolio adjustments following capital account liberalization have often led to a net capital inflow and real exchange rate appreciation. To summarize, these studies tell us that though capital account liberalization generally leads to a net capital inflow, fixed exchange rates may not be viable when the capital account is liberalized. Nevertheless, financial and capital markets interaction causes a large movement of capital and a greater probability of crisis.

\section{Asian Financial and Capital Account Liberalization}

Now we turn to studies of financial and capital account liberalization in the five affected Asian countries. Binhadi (1994) reports that Indonesia had liberalized the exchange rates and the capital account in 1970 while tax reform and trade and industry deregulation began only in the second half of eighties. In June 1983, determination of interest rates was left to each bank's discretion. Before October 1988, the private banks and foreign banks were not permitted to enter the banking sector. Kiriwat (1994) finds that after achieving fiscal balance and export success, the financial authorities in Thailand removed all interest rate ceilings gradually between 1989 to 1992. At the same time, the authorities felt that the securities market needed to be strengthened to provide both a counterweight to the power of large banks and give corporate managers instruments to manage their cash flow and risk.

Zialcita (1994) studies external account liberalization in the Philippines. The Philippines had full current account convertibility in 1981-82, but capital account restrictions remained pervasive. Following the balance of payments crisis and debt moratorium of October 1983, a 
floating regime was established. In 1991, the Philippines permitted full inflow of capital and limited outflow capital to $\$ 1 \mathrm{~m}$ per investor per year. Dooley (1994) notes that capital account liberalization in Malaysia and Indonesia (and in Chile and Mexico) was followed by large inflows of foreign capital. In addition to the usual 'pull' and 'push' factors, speculative bubbles and government policies were behind these inflows. Poorly informed private investors were merely following a 'follow the leader' game. ${ }^{4}$ Government policies of maintaining fixed exchange rates obviated the exchange rate risk. Though private investors/creditors expected the bubble to burst, they expected the government or the IMF to bail them out since they (IMF or the government) would not like the depositors hurt. Thus, he had noted in 1994 that capital inflows in some Asian countries involved moral hazard.

Johnston, Darbar, and Echeverria (1997) provide detailed information on the sequence and incremental nature of reforms of domestic and external transactions in Indonesia, Korea, and Thailand (and Chile) for the 1985-96 period. This information is reviewed against the balance of payments developments and macroeconomic and exchange rate policies in these countries. They favor a coordinated and comprehensive approach to reforms of these two sectors. They also suggest that managing capital flows successfully depends critically on the overall incentivestructure causing these flows and the stage of development of the domestic financial system.

Thus, the affected Asian countries mostly retained fixed exchange rates and had fairly liberal financial and capital sectors in place by 1997. However, they lacked either awareness or will/expertise to adequately supervise or regulate the financial sectors.

\section{Asian Crisis: Diagnosis and Prognosis}

Asian countries' economic performance was being held up as a model for other countries as late as April 1997. For example, Ito (1997), using the 'flying geese' hypothesis, identifies Japan, 
flying in front, flanked by Hong Kong and Singapore, and followed by Korea and Taiwan as miracle economies. He noted that Malaysia, Thailand, Indonesia, and the Philippines were just behind them in economic success. For example, during the thirty years preceding the crisis, per capita real income levels increased tenfold in Korea, fivefold in Thailand and fourfold in Malaysia. All these countries had high savings and investment rates, were applying modern scientific thought and technology to industry, and had highly trained labor forces. A major crisis in these economies begs for answers. We present the following explanations.

\section{Low Marginal Productivity of Capital}

One reason for the Asian crisis is that marginal productivity of capital had fallen quite low in these countries by 1997. Young (1994, 1995), Kim and Lau (1994), and Krugman (1994) argue that most of East Asia's remarkable success preceding those years was attributable to factor accumulation (including capital accumulation) rather than to miraculous achievements in productivity. An implication is that East Asia had excessive investment whose marginal productivity had substantially fallen. Investors' sudden realization of this low return on real investment in the affected countries was one cause of the Asian crisis. This structural problem was not widely recognized before 1997 .

\section{Minsky's Financial Instability Hypothesis}

The Asian experience lends some support to Minsky's (1986) financial instability hypothesis that a country's economic success carries the seeds of a later financial crisis. Minsky argued that economic booms cause both lenders and borrowers to take risks they otherwise would not. Such risk taking results in financial instability as borrowers seek cash to finance acquisition of additional capital goods and lenders willingly provide it. Any shock to the system can easily push the borrowers into insolvency. Hardy and Pazarbasioglu (1998) find some evidence of this 
financial instability in Asia. Asian countries had a higher than average relationship between banking sector distress and credit growth. They also had excessive buildup in the foreign liabilities of the banking sector.

\section{Fixed Exchange Rates and Un-Hedged Borrowings}

Washington-institutions (IMF and the U.S. Treasury) have stressed the maintenance of relatively fixed exchange rates as one of the causes of the crisis. The exchange-rate confidence, solvency, and debt crises that erupted in the affected economies in mid-1997 was not a result of the usual macroeconomic imbalances. The fixed-exchange rates led banks and corporations in the affected countries to borrow large amounts of short-term, foreign currency denominated unhedged foreign capital that was used to finance poor quality investments.

\section{'Push' Factors and Rise in Country Risk}

The preceding explanation raises the question why fully rational lenders/investors lent and invested in such low-quality investments. It appears that 'push' factors, viz. low rates of return available to financial institutions in Japan and the U.S., and vent of surplus of investible funds for whatever diversification existed, combined with optimistic expectations were responsible for flows to these countries. Yet, in the middle of 1997, the lenders/investors revised their returnexpectations downwards and risk-expectations upwards and suddenly pulled their funds back.

Chinn and Maloney (1998) for Korea and Taiwan, and Maloney (1997) for Chile find that in spite of capital account liberalization, covered interest parity (CIP) did not hold for these countries. Covered interest parity has been used as a test of capital accounts' integration. These countries' capital markets therefore were not well integrated with world markets. However, CIP only adjusts for expectations of exchange rate depreciation. One should instead argue that these countries had higher 'country-risk.' In the middle of 1997, country-risk of the East Asian 
economies suddenly increased. Nevertheless, their real interest rates did not rise either speedily or sufficiently. The result was capital flight and currency and asset-value crises.

\section{Regionalization and Contagion}

The conventional wisdom is that the 1990s have been 'the decade of globalization.' This preconception does not recognize the simultaneous increase in regional linkages. During the past decade, regional economic links have intensified more than extra-regional ones. Trade among industrial countries in different regions has declined in relative terms while linkages between developed and emerging market economies within regions have increased. In addition, intraregional trade among emerging market countries has been the fastest-growing category of all. For example; despite strong export to non-Asian trading partners, intra-Asian trade (among developing countries has grown even more rapidly so that intra-regional exports as a proportion of total exports increased as illustrated by Table 6.4. The contagion to the other Asian countries can be partly explained by the recognition of these regional links by investors.

\section{Institutional Factors}

The Asian crisis shows that there are important differences between financial and other markets. These differences suggest that although there is a presumption that trade liberalization is welfareenhancing, full liberalization of financial markets may well not be because it is associated with a higher probability of crisis Financial markets will promote growth only if they have sturdy institutions to help them do their work, including strong government regulation, effective laws, and vigilant enforcement. The affected Asian countries had largely liberalized their financial and capital account sectors even though they lacked · such sturdy institutions. 


\section{Comparison to the Chilean and Mexican Crises}

Chile: Chile is one country where financial liberalization was taken to mean no regulation. Chile privatized its banks and liberalized exchange rates in 1974 Capital controls were completely removed by 1980. During this period several banks and whole saving and loan system collapsed. Some banks had no capital and the incidence of connected lending within financial-industrial groups was high. Recession and serious deterioration in the terms of trade in early 1980s led to large reversals of capital flows. The bad debts of banks accelerated rapidly because of exchange rate and interest rate-lined losses.

The Chilean crisis of early 1980s, like the Asian crisis, was also manifested by a reversal of private capital flows. Still, it differs from the Asian crisis in the following ways: First, unlike the affected Asian countries, Chile's banking and financial sector was already on the verge of collapse before the crisis. Secondly the Chilean crisis was triggered by events in the real sector, viz. recession and sharp deterioration in the terms of trade. On the other hand, the Asian crisis started with the sudden fall in confidence in Thai Baht's exchange value.

Mexico: Mexico was a large recipient of foreign capital in the period preceding its 199495 crisis. In fact, \$104b of capital flowed into the country between 1990 and 1994 - it was 20 percent of total capital flows to developing countries during this period. However, most of this capital consisted of portfolio equity investment. None of the affected Asian countries experienced such large capital inflows preceding the crisis. Also, the dominant equity investment in these countries was direct rather than portfolio. Direct flows to Asian countries did not reverse during the crisis years. It was largely the reversal of short-term bank lending that characterizes the Asian crisis. 
As stated above, one reason for the Asian crisis was the excessive boom in real investment in these countries. The boom had been going on for decades. The situation in Mexico was different. For ten years preceding 1989, Mexico experienced low or negligible growth and high inflation. From 1989 to 1994, Mexico's average GDP growth rate was 3.9 percent, and, inflation in 1993 fell to single digit levels for the first time in over 20 years. Thus, Mexico was not suffering from either a long boom in investment that had reduced the marginal productivity of capital in 1994 or from Minsky's financial instability in the last phase of a boom. Rather it was political (and suspected criminal) events revealed in December 1994) that caused the Mexican crisis. After the rescue package was put together, the crisis was quickly contained. The Asian crisis proved to be so enduring because it has demonstrated some structural problems of these economies. 5,6

\section{Conclusions}

The return on financial investments in the U.S. (at least of the fixed income type) and Japan have been quite low. One source of these funds are prodigious Japanese savings coupled with its negligible (till recently) growth. For U.S., the wealth effects due to the 1990s boom, rising income inequality, and the maturing of the baby-boomers all provide a 'push' for new markets. These factors provide great opportunities for developing countries as a destination for capital flows. However, the Asian crisis, like the Mexican crisis of 1994-95, also shows the challenge of sustaining the confidence of foreign investors. Any unexpected development/shock can cause panic and 'run' on the country. Thus, developing countries ought to strengthen their institutions at the same pace as they liberalize their financial sector and open-up their capital accounts. The theoretical models discussed in this paper assume open economies, full information, and efficient global financial markets. The former two assumptions are particularly inappropriate for 
developing countries. In the 1980s, the information asymmetry between local firms/banks and foreign investors about local business conditions in Latin America was mitigated by government guarantees to foreign investors. Yet, as the experience of the 'lost decade' of 1980s showed, even sovereigns' may default. Imperfect information models are needed as alternatives to the current full-information open-economy models. Furthermore there is a need for additional studies of the interaction of financial and capital account liberalization both to explain the Asian crisis and to understand this increasingly important part of modem economies. 


\section{Notes}

1. Other parts of the world have not been immune from contagion from the Asian crisis, the Russian economy was performing poorly in any case. But, Latin-American economies, including Brazil, arguably may have avoided their woes in the absence of contagion from the Asian crisis. This crisis has clearly exacerbated economic problems in many parts of the world. For example, the following economies (in addition to the five affected countries) have experienced recession (fall in output for two consecutive quarters) since the Asian crisis: Singapore, Hong Kong, Japan, Germany, Argentina, Brazil, Chile, Colombia, Venezuela, South Africa, Romania, Ukraine, Turkey, and the Czech Republic. See, the World Bank (1999) and International Financial Statistics, various monthly issues. This crisis and its aftermath placed the global real economy to one of its greatest perils since the Great Depression.

2. The decline in real estate prices in these economies is equally sharp.

3. Please see various monthly issues of the International Financial Statistics for these data.

4. The gradual liberalization from 1985 to 1996 of monetary controls and financial system, exchange system, trade and capital flows for Chile, Indonesia, Korea, and Thailand is brought-out very clearly by Johnston, Darbar, and Echeverria (1997).

5. The 'push' factors (external or exogenous developments) like low rates of return in investing countries and investors' desire for diversification may be contrasted from 'pull' factors like policy reforms, regulatory changes, and a more attractive investment climate in the borrowing countries. See Calvo, Leiderman, and Reinhart (1993) for the use of these terms.

6. Mexico overcame its structural problems by undertaking reforms during the 'lost decade' of the 1980s and during early 1990s. 


\section{References}

Bartolini, Leonardo and Drazen, A. (1997), Capital-Account Liberalization as a Signal, American Economic Review, vol. 87, pp.138-154. .

Binhadi, P. (1994), 'Financial Deregulation and Bank Supervision: The Case of Indonesia', in Faruqi, Shakil (ed.), Financial Sector Reforms, Economic Growth, and Stability, Experiences in Selected Asian and Latin American Countries, The World Bank, Washington, DC.

Bruno, Michael. (1996), Deep Crises and Reform, What Have we Learned?, The World Bank, Washington, DC.

Calvo, G. A., L. Leiderman and C. Reinhart. (1993), 'Capital Flows to Latin America:The Role of External Factors.' IMF Staff Papers, vol. 40, pp.108-51.

Chinn,Menzie D. and William F. Maloney. (1996), 'Financial and Capital Account Liberalization in the Pacific Basin: Korea and Taiwan During the 1980s,' International Economic Journal, 12, $53 \cdot 74$.

Demirguc-Kunt, Asli and Enrica Detragiache. (1998), 'Financial Liberalization and Financial Fragility,' presented at the Annual World Bank Conference on Development Economics, The World Bank, Washington, DC.

Dooley, Michael. (1994), 'Globalization, Speculative Bubbles, and Central Banking,' in Faruqi, Shakil (ed.) Financial Sector Reforms, Economic Growth, and Stability, Experiences in Selected Asian and Latin American Countries, The World Bank, Washington, DC.

Goldfajnllan and Rodrigo O. Valdes. (1997), 'Capital Flows and the Twin Crises: The Role of Liquidity', Working Paper, 97/87, The International Monetary Fund, Washington, DC.

Haggard, Stephen and Sylvia Maxfield (1996), 'The Political Economy of Financial Internationalization in the Developing World,' International Organization, vol. 50, pp.35-68.

Hardy, Daniel C. and Ceyla Pazarbasuoglu. (1998), 'Leading Indicators of Banking Crisis Was Asia 
Different?' Working Paper, 98/91, The International Monetary Fund Washington, DC.

Institute of International Finance (1999), Capital Flows to Emerging Market Economies, Washington,

DC, April 25 and September 25, and detailed data for the five affected Asian economies provided

by its staff.

International Financial Statistics, various monthly issues, Washington, DC.

International Monetary Fund (1999), Direction of Trade Statistics, 1996-Yearbook and June 1999-Quarterly, Washington, DC.

Ito, Takatoshi. (1997), 'What can Developing Countries Learn from East Asia's Economic Growth,' Annual World Bank Conference on Development Economics, The World Bank, Washington, DC.

Johnston, Barry R., Salim M. Darbar and Claudia Echeverria. (1997), 'Sequencing Capital Account Liberalization: Lessons from the Experience in Chile, Indonesia, Korea, and Thailand', Working Paper, 97/157, The International Monetary Fund, Washington, DC.

Kim, Jong-II and Lawrence J. Lau. (1994), 'The Sources of Economic Growth of the East Asian Newly Industrialized Countries,' Journal of Japanese and International Economics, vol. 8, pp.235-71.

Kiriwat, Ekamol. (1994), 'Securities Market Regulations and Reforms in Thailand,' in Faruqi, Shakil (ed.), Financial Sector Reforms, Economic Growth, and Stability, Experiences in Selected Asian and Latin American Countries, The World Bank, Washington, DC.

Krugman, Paul. (1994), 'The Myth of Asia's Miracle,' Foreign Affairs, pp.62-78.

Le-Fort, Guillermo. (1994), 'The Financial System and Macroeconomic Stability: The Chilean Experience,' in Faruqi, Shakil (ed.), Financial Sector Reforms, Economic Growth, and Stability, Experiences in Selected Asian and Latin American Countries, The World Bank, Washington, DC.

Maloney, William F. (1997), 'Testing Capital Account Liberalization without Forward Rates, Another Look at Chile 1979-1982', Journal of Development Economics, vol. 52, pp.39-168. 
Mathieson, Donald J. and Liliana Rojas-Suarez. (1993), Liberalization of Capital Account, Experiences and Issues, The International Monetary Fund, Washington, DC.

Minsky, Hyman P. (1986), Stabilizing an Unstable Economy, Yale University Press, New Haven and London.

Park, Daekeun. (1994), 'Foreign Exchange Liberalization and the Viability of a Fixed Exchange Regime,' Journal of International Economics, vol. 36, pp.99-116.

World Bank (1999), World Development Report, Washington, DC.

Young, Alwyn. (1994), 'Lessons from the East Asian NICs: A Contrarian View,' European Economic Review, vol. 38, pp.964-973.

Young, Alwyn. (1995), 'The Tyranny of Numbers: Confronting the Statistical Realities of the East Asian Growth Experience', Quarterly Journal of Economics, vol. 110, pp.641-680.

Zialcita, Edgardo P. (1994), 'Capital Account Liberalization: The Philippines Experience,' in Faruqi, Shakil (ed.), Financial Sector Reforms, Economic Growth, and Stability, Experiences in Selected Asian and Latin American Countries, The World Bank, Washington DC. 


\section{Data}

Table 6.1 Depreciation in Asian Exchange Rates

Percent change from:

July 1, 1997 Dec. 31, 1997 July 1, 1997

to

to

to

Dec. 31, 1997 May 1, 1998 May 1, 1998

$\begin{array}{lrrr}\text { Indonesia } & -55.8 & -31.2 & -69.6 \\ \text { Korea } & -47.5 & 26.7 & -33.5 \\ \text { Malaysia } & -35.2 & 5.7 & -31.5 \\ \text { Philippines } & -34.5 & .6 & -34.9 \\ \text { Thailand } & -47.6 & 21.2 & -36.5 \\ \text { Japan } & -11.9 & -1.9 & -13.6 \\ \text { China } & .1 & .4 & .5 \\ \text { Hong Kong } & 0.0 & 0.0 & 0.0 \\ \text { Taiwan } & 15.2 & -.8 & -15.8 \\ \text { Singapore } & -15.4 & 7.0 & -9.5\end{array}$

Note: Calculated from various issues of the IMF's International Financial Statistics.

Source: Bloomberg Financial Services, L.P

Table 6.2 Depreciation in Asian Stock Indices

Percent change from:

July 1, 1997 Dec. 31, 1997 July 1, 1997

to to to

Dec. 31, 1997 May 1, 1998 May 1, 1998

$\begin{array}{lrrr}\text { Indonesia } & -45.4 & 14.5 & -37.0 \\ \text { Korea } & -51.6 & 11.9 & -45.8 \\ \text { Malaysia } & -45.7 & 6.2 & -42.3 \\ \text { Philippines } & -32.4 & 16.7 & -21.1 \\ \text { Thailand } & -35.7 & 12.7 & -27.5 \\ \text { Japan } & -24.4 & 2.5 & -22.6 \\ \text { China } & 1.5 & 13.7 & 12.0 \\ \text { Hong Kong } & -28.6 & -3.5 & 31.0 \\ \text { Taiwan } & -9.5 & 1.9 & -7.7 \\ \text { Singanore } & -13.8 & -8.9 & -21.3\end{array}$

Source: Bloomberg Financial Services, L.P. 
Table 6.3 External Financing in Five Asian Economies (Billions of Dollars)

$\begin{array}{lrrrrr} & \mathbf{1 9 9 5} & \mathbf{1 9 9 6} & \mathbf{1 9 9 7} & \mathbf{1 9 9 8} & \mathbf{1 9 9 9 f} \\ \text { Current account balance } & -40.6 & -54.4 & -26.8 & 69.4 & 46.3 \\ \text { External financing, net } & 89.0 & 103,2 & 27.5 & -12.9 & 10.8 \\ \text { Private flows, net } & 86.4 & 106.4 & -0.8 & -38.6 & 5.1 \\ \text { Equity investment, net } & 15.3 & 18.6 & 4.4 & 14.2 & 25.2 \\ \text { Direct, net } & 4.2 & 4.7 & 5.9 & 9.9 & 11.9 \\ \text { Portfolio, net } & 11.0 & 13.9 & -1.5 & 4.3 & 13.2 \\ \text { Private creditors, net } & 71.2 & 87,8 & -5.2 & -52.7 & -20.0 \\ \text { Commercial banks, net } & 58.6 & 59.9 & -17.2 & -48.3 & -18.7 \\ \text { Nonbanks, net } & 12.6 & 27.8 & 12.0 & -4.4 & -1.3 \\ & & & & & \\ \text { Official flows, net } & 2.6 & -3.2 & 28.3 & 25.6 & 5.7 \\ \text { Int'l financial institutions } & -0.4 & -2.0 & 22.5 & 19.4 & -3.3 \\ \text { Bilateral creditors } & 3.0 & -1.3 & 5.7 & 6.3 & 9.0 \\ \text { Resident lending/other, net2 } & -34.3 & -31.9 & -31.3 & -15.1 & -13.5 \\ \text { Reserves (- = increase) } & -14.1 & -16.9 & 30.7 & -41.3 & -43.6\end{array}$

Source: Institute of International Finance.

Table 6.4 Trade among developing countries (intraregional exports as a percentage of total exports)

$\begin{array}{lrr} & \mathbf{1 9 8 7} & \mathbf{1 9 9 8} \\ \text { Within Asia } & 27.4 & 38.3 \\ \text { Within Latin America } & 15.2 & 22.0 \\ \text { Within Europe } & 34.6 & 36.4 \\ \text { Within Africa } & 5.8 & 11.9\end{array}$

Source: IMF, Direction of Trade Statistics 1996-Yearbook and June 1999-Quarterly. 